\title{
1. Introduction: contested concepts in gender and social politics
}

\author{
Barbara Hobson, Jane Lewis and Birte Siim
}

The purpose of the book is to present some of the key contested concepts in gender and social politics using cross-national perspectives and to contribute to the gendering of theory in the social sciences. Our approach is interdisciplinary, comparative and policy-oriented. It is interdisciplinary in that we integrate research in sociology, history, social policy and political theory. It is comparative in that we confront the convergences and divergences in the development of European welfare states. It is policy-oriented through our analyses of the shifts in political discourses and the changes in socio-political configurations that mirror changing gender relations. The research themes reflect our interest in the transitions of welfare states, democracy and citizenship, and focus on recent changes in the meaning and politics of social care, paid work, fatherhood and gender equality. We built our research around a common core of theories and conceptual vocabularies that we developed during a decade of cross-national and interdisciplinary dialogues. The authors were all participants in the European Network on Theory and Research on 'Women, Welfare State and Citizenship'1 and comprise the team of scholars who worked within the European Community thematic network: Gender and Citizenship: Social Integration and Social Exclusion in European Welfare States (1996-1999). ${ }^{2}$ The book is the fruit of a long-term research co-operation between this group of scholars that produced several books and articles (Lewis, 1993, 1997; Hobson, $2000,2001)$. The question arose of how to capture the richness of these dialogues in one book.

The idea for a book on contested concepts owes some of its inspiration to Raymond Williams' Keywords (1983). ${ }^{3}$ Like Williams, who came back from the war feeling that his compatriots were not speaking the same language, we too realized that three decades of gender research had joggled male-stream academic discourse and writing. Would we find a process of gendering within different conceptual reservoirs? As was true of the Keywords venture, we too began our project with a keen awareness of context, not only that concepts have a trajectory and meanings that accrue 
to them over time, as Williams understood, but also that relational meanings and interpretations exist across space, in different societies with different languages, histories, discursive frameworks and social politics.

Despite these common points of departure, ours is a very different project since we are not producing a lexicon of keywords and their different usages. Instead we are mapping the conceptual landscape of social politics that follows the markings of gender, which alters not only the choice of key concepts that we view as noteworthy but also their sites of contestation. Sometimes these markings are drawn in bold lines, such as in the key concept of care; at other times gender lies in the background, barely visible in discursive fields of concepts, as is the case in current academic and policy debates on social exclusion, and even more so in respect of social capital. Moreover, our attention to concepts, rather than keywords, suggests a different endeavour. We are not concerned with the social and historical processes that occur within language but rather the ways in which our conceptual vocabularies are shaped by social and historical and political processes. This involves something other than embedding our key concepts in layers of historical evolution: tracking their encounters with current policy debates, and listening to their salience or silence in public discourse. Our central question is whether and to what degree gender has destabilized or altered these conceptual vocabularies.

In some respects our project is more similar to the approach of Nancy Fraser and Linda Gordon (1994) in their study of the genealogy of the keyword, dependency. They also take for granted the ways in which concepts can reflect contested social politics. Focusing on one geographical context, the USA, they carefully plot the narratives of gender, race and class in shaping different ideological registers of dependency at different historical periods. However, we have a different strategy. Our primary interest is in the points of contestation themselves. These are expressed by different actors - scholarly, as well as political - who are engaged in the gendering of a conceptual territory. In short, we begin the other way around, not with how the ideological register has altered the construction of gender in discourse and policy, but with the ways in which gendered theorizing and empirical research have penetrated the conceptual terrain and policy arenas.

Instead of cutting a wide swath through the large tract of social politics and gender, we chose to furrow within a small area, and dig deep, selecting only seven concepts. Our choice of concepts was in some respects guided by our predilections and interests reflected in the dialogues that we had over the last five years as part of the thematic network on Gender and Citizenship: Social Integration and Social Exclusion in European Welfare States. But these are not merely idiosyncratic choices; in fact these con- 
tested concepts reflect a range of debates within social politics and gender over the last decades.

In presenting the theoretical concepts, we employ a historical approach, but the main focus is on the most recent decades. We begin by asking how the concept is situated within the landscape. This often involves making links between the chapters throughout the book. We examine the extent to which feminist theory influenced the theoretical boundaries of these concepts as well as the political debates. One of the objectives of the book is to locate each concept in different policy contexts, asking whether and in what ways it resonates in different nation states. Finally, we are interested in the extent to which each concept has been gendered.

The authors of Contested Concepts are scholars who have been involved in international research collaborations. They come from many countries in Europe: Belgium, Britain, Denmark, Germany, The Netherlands, Norway, Ireland, Italy and Sweden. To exploit the international and interdisciplinary features of this group, it was decided that each chapter would be coauthored by two scholars from different national backgrounds working from different theoretical frameworks, and sometimes also from different academic disciplines. The exception is social capital, which provides an overview of the current theoretical debates.

The selected key concepts represent issues and concerns in social and political thinking and in feminist thought related to women's civil, political and social rights, and to their participation, representation and power in social and political life. In asking how gender has challenged, destabilized and sometimes reconfigured the conceptual terrain in social politics, we can see a range of different situations. As a result of relentless and powerful challenges by feminist scholarship to male-stream gender-blind theorizing on the welfare state, we find fewer and fewer texts where gender is ignored. Gender has become embedded within the interstitial layers of concepts, such as citizenship, representation and de-commodification. Gender is integral to care; it is impossible to imagine a genderless discussion of care. Gender research has made fewer inroads into concepts such as contractualization and social exclusion, where gender dimensions remain at the periphery. Gender is conspicuously absent in the highly visible current academic and policy debates around the concept of social capital. But the chapter in this volume is a first step in the gendering process.

One of the crucial themes that has emerged as a background and premise for feminist scholarship and debates is the gendering of inequality during the past 30 years following women's demand for civil, social and political rights. In all Western democracies, the feminist movement has put gender equality on the political agenda and feminism has challenged the division between public and private, between paid work and care and between 
equality and difference. Feminist scholarship has been inspired by feminist politics and has started to re-conceptualize the links between civil society, the market and the state. And this has started to develop the cross-national dialogues and comparative research about women's empowerment and the role of women's political agency in influencing political decisions and welfare state developments. The chapters, all in different ways, question the meaning of and relation between the public and private arena, between paid work and care and between equality and difference. They do not deal explicitly with equality (and power) but they discuss the implications of the theoretical approaches, key concepts and social politics for gender equality and for women's private and public autonomy (power/ability to influence political decisions).

Two historical processes infuse much of our discussion of contested concepts: the demise of the post-war settlement reflected in the restructuring of welfare states, and the growing importance of global restructuring.

\section{WELFARE STATE RESTRUCTURING: POLITICS AND GLOBALIZATION}

Our consideration of key concepts has taken place at the end of a decade of profound restructuring of welfare states, which has in turn informed and influenced the discussion in the chapters that follow. The reasons for restructuring are many and the debate over their relative importance intense. This section briefly sketches the broad contours of change.

Modern states have always constructed social provisions around the paid work/welfare relationship; it is this that has in large measure distinguished them from needs-based and arguably universal, but punitively deterrent, poor law systems. Governments have always been concerned about the conditions for providing welfare - the nature of entitlements in the language of many policy analysts, but more as a matter of conditionality in the mind of government. There has been a long-standing firm conviction too, on the part of trade unions as well as governments, that wages are the best form of welfare. What was at stake of course in the early part of the twentieth century was the fight for the old style labour contract, to which social insurance, the core mechanism for the delivery of modern welfare, was successfully joined, and which is now under profound review (Supiot, 1999). The settlement at the heart of the modern welfare state was that between capital and labour. But it is increasingly recognized that there was a second key settlement between men and women. The old labour contract was designed first and foremost for the regularly employed male breadwinner and provision had to be made for women. 
The gender settlement meant that those marginal to the labour market got cash cover via dependants' benefits. Alain Supiot has described the labour/capital settlement in terms of security traded for dependence. A similar set of arrangements can be said to have marked the gender settlement. The male breadwinner model was based on a set of assumptions about male and female contributions at the household level: men having the primary responsibility to earn and women to care for the young and the old. Female dependence was inscribed in the model. The male breadwinner model built into the post-war settlement assumed regular and full male employment and stable families in which women would be provided for largely via their husbands' earnings and social contributions.

It is not difficult to see that the profound changes in both male employment, with the reoccurrence of mass unemployment and the increasing 'flexibilization' of labour markets, and in family structure, with high rates of breakdown and growing numbers of lone parent families, must inevitably impact on the whole edifice of social provision.

The changes in respect of the labour/capital settlement have been widely attributed to 'globalization'. Globalization is a contested term. It is certainly not a new phenomenon (Therborn, 2000), but in its late twentieth and early twenty-first-century form it may be broadly defined in terms of an increase in the international movements of goods, capital and (professional) labour. The evidence for globalization in respect of information and financial capital is overwhelming, but evidence regarding other dimensions is more mixed. Globalization is believed by a majority of neoclassical economists and a large proportion of politicians and policy makers to raise the economic costs of social programmes that redistribute income and provide economic security. The precise nature of the causal relationship that is involved is subject to considerable debate (see for example Gough, 1996; Bowles, 2000). But if more labour insecurity results from the increasingly global nature of the economy, and cuts to social programmes are deemed necessary to achieve competitiveness, these developments will be particularly problematic for women, whose leverage on the labour market has always been weak relative to men and whose complicated relationship to unpaid care work as well as paid employment makes them especially vulnerable to reductions in social provision, both as workers and as clients. Many commentators interested primarily in social policy issues have argued that internal factors, such as demographic change, are more important than the external factors associated with the concept of globalization in explaining the need for welfare state restructuring (Esping-Andersen, 2000). However, these are not necessarily competing explanations. Indeed, increasing individualization in respect of family change and labour market behaviour goes hand in hand and is reinforced by the changing nature of 
the assumptions that are made by policy makers influenced by 'globalization talk'.

To take the issue of labour market change (and increasing insecurity) first: flexibilization has increased dramatically over the past decade, with more short-term contracts, more part-time work and more insecurity. In the 1980s, the trade-off between equity and employment for low-paid workers worsened. Attention has been drawn particularly to the position of male manual workers in the USA (Wilson, 1987). More adult women have continued to enter the labour market and to stay in it. In all OECD countries, the labour market participation rates of women have gone up, while those of men have gone down. It is also the case that women are the most 'flexibilized' workers. As O'Reilly and Fagan (1998) have pointed out, flexible employment has often been the vehicle by which women have secured entry into the labour market; this would be true of 1990s Spain and The Netherlands, for example. Thus the issue of how to interpret flexibilization immediately becomes complicated. There are real problems of insecurity associated with flexible employment, but it may nevertheless offer opportunities to those already suffering marginalization. As the debate about welfare regimes shows, the process of commodification has been as or more pressing for women as the more commonly considered process of de-commodification under the traditional labour contract.

In addition it should be noted that the greater flexibility and insecurity of women workers is due to much more than the changed conditions of the labour market as a result of late twentieth century globalization. A significant proportion of the increase in women's employment in the postwar period, not just the 1990s, in a large number of OECD countries can be accounted for in terms of part-time work; in some countries, such as The Netherlands and the UK, it accounts for virtually the whole increase. Women's entry to the labour market has been historically conditioned by the circumstances of their partners (and of other household members). Hakim (1996) has argued controversially that a majority of women have chosen to follow the prescriptions of the male breadwinner model family, with only a minority of women choosing a career as opposed to a job that is perceived to take second place to the unpaid work of care.

Duncan and Edwards (1999) have also characterized the desire of lone mothers to put child-rearing first and paid work second as amounting to an 'alternative moral rationality'. However, recent comparative work (Crompton, 1999; Rubery et al., 1999) has insisted on a major role for institutions and structures, particularly in the form of social policies, in shaping gender relations and employment (see also Folbre, 1994; Scheiwe, 1994). In other words, constraints, such as lack of child care provision (shown by Bradshaw et al., 1996 to be the key variable determining the labour market 
participation rates of lone mothers cross-nationally), the disincentive effects of means-tested benefits systems for women who live with unemployed husbands and who wish to enter the labour market (Rake, 2000), or the disincentive effect of couple-based as opposed to individualized tax systems (Dingledey, 2000) are significant. Thus family circumstances and the social policies of nation states are important explanatory variables in determining the kind of work women do and their eligibility for social programmes.

In regard to the argument that globalization leads to cuts to social programmes, which render women especially vulnerable, the evidence is again far from clear-cut. Tanzi (2000) has warned of the future threat posed to the tax base. However, Stephens et al.'s (1999) comparative study of welfare state retrenchment found an absence of expansion, which they interpreted to mean a curtailment of social entitlements, but little by way of a 'race to the bottom'. Indeed, continental welfare systems have proved remarkably resilient, undertaking reform that has served to reinvigorate, or at the least 'recalibrate' their systems (Levy, 1999; Pierson, 2001). Even in the UK, which Stephens et al. (1999) felt was one of the three cases of ideologically driven change (alongside New Zealand and the USA), national data have shown deep cuts in public expenditure only in the field of housing (Hills, 1990; Glennerster and Hills, 1998), which is not to deny that substantial welfare state restructuring took place. Cuts and restructuring occurred in the major programmes of the welfare state, especially in respect of benefits for the unemployed and in pension provision, but in many countries policies that endeavour to reconcile work and family responsibilities actually expanded, albeit from a much lower base (Daly and Lewis, 2000). This has been notably true in the UK since 1997. Social policies have been important in mediating the erosion of the male breadwinner model and have taken very different forms in different European countries; in the USA the state played a very little role in this respect.

In regard to women and welfare, the most significant effect of globalization has been the way in which it has influenced change in the whole approach of governments to social provision. David Piachaud (2000) has underlined the influence achieved by the 'Washington Consensus' in prescribing for social policies private rather than public provision, allocation by markets rather than on the basis of need, targeting rather than universal provision, charging rather than tax-based finance and decentralization rather than central planning. In the name of competition and achieving growth, these means became confused with ends and tended to ignore institutions and the role of government. The effects of globalization on the assumptions informing the restructuring of welfare benefits in the 1990s have probably been more dramatic than on cuts in social programmes. The 
increased demands for competitiveness have lent support to major welfare state services that can be perceived as increasing human capital (chiefly health and education), while at the same time serving to justify a tougher approach to cash benefits, with a call to match entitlements to benefit with concomitant responsibilities to train or to work. This has been particularly strong in the USA and the UK and has served to transform ideas about social citizenship, although in the UK there is evidence to support the idea that the introduction of the minimum wage and the decisive move towards in-work benefits were prompted as much by a desire to improve the employment/equity trade-off for low-paid workers (Vandenbroucke, 1998).

Restructuring in some continental European countries - widely condemned as 'sclerotic' for their attachment to a social insurance welfare state and for their high unemployment rates - has also managed to turn 'vice into virtue', to use Jonah Levy's (1999) terminology. Thus France has turned its family allowance system into an anti-poverty measure by targeting; Italy has reformed its manifestly unfair pension system; and The Netherlands has focused on employment creation and labour market reform. In the UK, Howard Glennerster (1999) has expressed the view that we may now be seeing the emergence of a new kind of welfare state altogether. In the UK we see a strong commitment to basic welfare services alongside an acceptance of the low-wage, flexible labour market that was created by successive Conservative governments, together with a commitment to both in-work subsidies (first via the benefit system and now via taxation) and labour market activation programmes (the so-called New Deal).

However, the globalization thesis directs the attention of governments to labour markets and competitiveness and this discourse is dominant. In addition, it feeds into concern about the rapid changes in family structure, stressing as it does the importance of full, adult labour market participation on the part of men and women. European Commission documents show this clearly. The Commission has stressed the importance of adult labour market participation in the context of a strategy to increase European competitiveness (CEC, 1993, 1995). In the economic strategy of the Commission there is little reference to the family and family responsibilities, yet there is also obvious concern at the EU level with the work/family nexus, as expressed, for example, in the Directive on Parental Leave (96/34). The point is that these two agendas remain parallel and separate, but the fact that the globalization and competitiveness agenda is stronger has significant implications for women, chiefly because of the gendered division of care work.

The constraints of a global economy have been used by Western governments and the European Commission as a justification for emphasizing the requirements of competitive efficiency. Nowhere is this more apparent than 
in the ideas informing the 'third way', which as Jordan (1998) has pointed out takes the moral high ground in seeking national regeneration, ethical principles and the common good, social inclusion and cohesion, and selfdiscipline, all of which are felt to be embodied in a commitment to the work ethic. This has arguably been most strongly articulated in the Englishspeaking countries, although the 'Dutch miracle' (Visser and Hemerijcke, 1997) and the joint Blair and Schroeder (1999) document on the 'third way' are evidence of similar strategic thinking elsewhere. The stress on the responsibility of the citizens seeking support from the state to engage in paid labour was first encountered in the work of US commentators in the 1980s (especially Mead, 1986). In the US debate, the emphasis on securing greater labour market participation was about securing a better balance between social entitlements and responsibilities, and about removing people from the welfare rolls. Welfare-to-work programmes were implemented in a more or less draconian fashion. The road to competitiveness took the form of a low-wage, flexible, full-employment economy, in which all adults were expected to participate.

In Europe the stress on the responsibility to participate in the labour market took a somewhat different tone. 'Labour market insertion' has been viewed as the means to combat social exclusion, although the idea of active citizenship has been grounded in the responsibility to work. The 'third way' seeks to avoid both the stress on entitlements rather than rights, and the stress of neo-liberalism on the individual pursuing his or her self-interest and resulting in a 'dutiless individualism' (Plant, 1998). This may be so, but it also seems that the enthusiasm for the work ethic, fuelled by the globalization agenda, has brought about a shift in assumptions on the part of many Western governments from a male breadwinner ideal family form to an adult citizen worker ideal family form. Part of the idea is to promote social inclusion, but part of the idea is that wages will enable more selfprovision in the social arena (especially in respect of pensions). The new welfare contract involves a shift from social contributions to individually defined contributions, premised on the idea that all adults are in the workforce. But this is an especially unreal assumption for women, given, first, the unequal gendered division of unpaid care work, and second, the fact that a disproportionate number of them are employed in low-paid, parttime, often care-related jobs. It is additionally the case that in the UK, where these shifts are most apparent in Europe, the means-tested nature of the whole social security system tends to run counter to individualization.

This drift towards greater individualization in labour market behaviour, family formation and social provision, fuelled by the globalization debate, has major implications for women. It stresses the importance of paid work and increasingly assumes that individuals will take more responsibility for 
their own welfare, particularly in respect of old-age pensions. It has less to say about care. Yet the gendered division of unpaid as well as paid work has always been central to understanding women's position in modern welfare states. There remain significant tensions in respect of care work. For example, the proponents of social capital call attention to 'the family's' although not always to the unpaid work of women within it - part in providing the underpinnings for successful market-based liberal democracies. It is significant that the issue of unpaid care work surfaces in more than one chapter in this book. It is central to the state/market/family relationships that have long been recognized as structuring our understanding of social provision, but it has yet to take first place in welfare state restructuring.

More specifically, it is important to begin the work of addressing gendered dimensions within the context of global economic, political and cultural processes. Policy making within national contexts appears more and more bound to international policy arenas and discursive landscapes. This is not to suggest the erosion of state sovereignty, but rather to underscore ways in which states are complicit in what are claimed to be inevitable economic processes (Marchand and Runyan, 2000; Pierson, 2001; Stephens et al., 1999). Little attention has been paid to gendering the scripts of globalization. This can be seen at both the discursive and policy levels. On the discursive level, global processes are coded as masculine; in the neo-liberal frame the state sector is constructed as feminized, weak and unable to compete in a rigorous economic arena, seen as a "drag on the global economy' (Marchand and Runyan, 2000, p. 14). Implicit in this imaging is recognition that the state is a major employer for women in the public sector, work that often provides the care services that allow women to combine work and family life. From this neo-liberal position, the way to reinvigorate or remasculinize this weak state is through reprivatization of services (Marchand and Runyan, 2000). Privatization in care is interlocked with global restructuring and those implementing these changes - ministries of finance - are designated masculine.

In everyday policy making, ministries of finance and economic affairs have become the dominant actors in most Western democracies, a strategy governments adopt to position themselves in the competitive conditions of global finance, trade and production. They are steering both policy making and politics. Their dominance in policy making places constraints on feminists' claim making, their access to power and discursive resources in political arenas. Women's collectivities and lobbying have been most able to influence or hold positions in the health, education and welfare ministries. Ministries of finance tend to be insulated from public accountability except for business groups, and act as if financial global issues are gender neutral. Looking at concepts such as contractualization, citizenship and 
social exclusion through a gendered lens, we have been able to bring into focus the ways in which supranational actors and processes configure national ones.

Global restructuring has also had an impact on feminist theorizing on public and private, and the sites of resistance against gender inequalities. For women in the transition countries of Eastern Europe, the collapse of communism accelerated global restructuring and this has resulted in heated debates around the role of the state as a potential ally for women's movements in those countries. Women in former Soviet Union countries do not view the state as a place for making claims for two reasons: (1) because of their distrust of the state as a result of the surveillance and invasive practices of the regime on private life (hence, the family was a site of resistance); and (2) for at least some women, the private market has afforded them new avenues for careers and opportunities to create pastiches of different jobs and mixes of paid and unpaid work, as well as a broader range of consumer goods (see Szalai, 2000; Gal and Kligman, 2000).

New actors and claim making emerge in supranational forums. Transnational NGOs and international forums and networks shape the discursive resources and types of claim making in social movements. The UN conferences held in Cairo in 1994 and in Beijing in 1995 come to mind as examples. As this is a book that focuses on European societies, the EU figures as a key actor. The authors interrogate the implications of global arenas and supranational institutions in the contested conceptual landscapes of citizenship, care, contractualization, de-(commodification), representation and social exclusion.

Comparative empirical research indicates that different welfare states respond differently to the forces of globalization, and until now there have been relatively strong path dependencies in the way in which European welfare regimes respond to the perceived threats of globalization. The different welfare regimes express different policy logics, and feminist scholarship has shown how they also embody different relations between state, market and the family. We have already noted that increasing flexibilization in the labour market and individualization as a result of both labour market and family change create problems and possibilities for women. In regard to paid work/care feminist scholarship has identified a shift in the policy logic of the welfare state from a male breadwinner towards an adult worker model that aims to integrate all citizens on the labour market including mothers (Lewis, 2000, 2001). This has politicized the paid work/care nexus and has arguably opened new possibilities to place the work/care relation on the political agenda and to expand public services towards children and the elderly. The inclusion of women in the labour market represents a shift in policy logic towards an adult worker model that 
has huge implications for the politics of care. This trend has been visible in the Nordic welfare states since the 1970s, and in Denmark and Sweden women today have the highest labour market participation rates in the OECD countries. In Denmark and Sweden women's part-time work has declined during the 1990s, and married mothers have activity rates as high as single women. At the same time there has been an expansion of public services for the care of children, and proactive policies to increase men's participation in family life - a month of parental leave is reserved for fathers in Sweden and Norway.

The important role of the family in the restructuring of the welfare state has increasingly been recognized by researchers and policy makers, and it has been followed by new attempts to conceptualize the key role of households in the post-industrial economy. Responding to a decade of feminist criticism, Gösta Esping-Andersen, in his latest book, places the family at the centre of the analysis of welfare state restructuring, arguing that the household economy is indeed alpha and omega to any resolution of the main post-industrial dilemmas, for example around equality, risks and jobs (Esping-Andersen, 1999, p. 6). Though the family dimension of the institutional triangle (state, market and family) is elaborated in this book, the gendered implications are missing. Lacking in the analysis is the idea that welfare states have different caring regimes. There are contradictory tendencies connected with individualization and changing family structures, and during the 1990s women's integration into the labour market has been followed by different policy responses to problems of reconciling paid work and care. In Western welfare states the growing shortage of caring resources has been acknowledged as a 'caring deficit' (Hochschild, 1995). Arguably increasing women's economic independence and minimizing family dependencies requires a radical recasting of collective responsibilities. Female independence necessitates what has been called the de-familialization ${ }^{4}$ of welfare obligations and social policies committed to lessening the caring burden of the family (Lister, 1997; Saraceno, 1997).

De-familialization policies have indeed only been a political strategy in the Nordic countries whereas other Western countries - corporatist and liberal - have historically assigned a maximum of welfare obligations to the family or to the market. A paradox of our times is that countries with a familialistic policy logic, such as Germany and Italy, have some of the lowest fertility rates, whereas Sweden with its de-familialization policies had one of the highest up until the economic crisis of the 1990s, which has precipitated a dramatic decline in birth rates. It is still true that female employment levels are positively related to fertility rates, and the fertility effect of a service-based welfare state is quite strong. Arguably, increasing the service intensity of welfare states should help to reduce unemployment 
(Esping-Andersen, 1999, p. 70). One controversial issue for further research is whether there is indeed a move towards a convergence or divergence in terms of European social and family policy, or whether they are moving along different paths of adjustment.

During the 1990s the politics of care has been high on the political agenda in Western European welfare states and intensely debated. The restructuring of care takes several forms that may either challenge or reproduce gender inequality. The participation of citizens in the formulation and implementation of social politics and social policy is a crucial dimension of comparative welfare state analysis (Siim, 2000). The welfare state restructuring and the future politics of care may also depend on the will and ability of citizens, especially women citizens, to influence social politics. Here again, there are problems and possibilities for women. Globalization and European integration have contributed to diminishing the power of the nation states, and researchers have identified a crisis of representation and a democratic deficit in modern democracies. But at the same time women have increased their participation in civil society and representation in political institutions.

The tendency towards a more equal representation of women and men is again most visible in the Nordic context, where women today make up about 40 per cent of the representatives. But it is also visible in France, where a recent policy reform inscribed the principle of equal representation directly in the constitution. The trend towards a feminization of the political elite either through parity or gender quotas is contested. It can be interpreted both as a means to give women citizens 'a voice and a vote' as well as an indicator of women's powerlessness and their inclusion in 'shrinking institutions' (Bergqvist et al., 1999). The feminization of the political elite may be important in itself, but arguably it may also open new possibilities for women citizens to influence social politics by placing gender equality and women's issues on the political agenda. The inclusion of women in democracy does not solve the democratic deficit or the crisis of legitimation between representatives and those represented, and there are indeed growing problems in modern democracies with the political integration of other types of difference represented by immigrant and refugee groups.

\section{FEMINIST APPROACHES TO KEY CONCEPTS IN SOCIAL POLITICS}

Within feminist theorizing on social politics, there are central dilemmas that pervade our analyses of contested concepts. Three of these are central to the chapters that follow. One is the private/public split, which is 
intertwined with the debates over equality and difference. Another is the multidimensionality of the category of gender, which is significant in the contested politics of feminism and feminisms. Finally we consider contested positions along the philosophical boundaries of an ethic of care and an ethic of justice, which embrace other debates around paid and unpaid work, commodification and de-commodification, as well as the disputes in the equality difference debates.

The chapters on citizenship (Chapter 2) and contractualization (Chapter 5) trace the theoretical foundations and the different faces of the public/private in contemporary policy debates. The delineation of public and private spheres into masculine and feminine domains was inscribed in the Enlightenment narratives of the origins of contract and citizenship rights and obligations. Male citizens were accorded rights and duties as rational beings capable of exercising them; women were codified as noncitizens outside the public sphere, set apart by their dependency, their lack of civil rights and political agency, and their relegation to the private world of the family and domestic life. Though women have gained many of the civil and political rights denied them in the past, the inequalities implicit in the demarcation between public and private remain. Contemporary feminist political theorist Carole Pateman, who addresses the consequences of this legacy, maintains that what is consigned to the private continues to be devalued (women figure as lesser citizens in this differentiated model); yet when women are incorporated into the public gender-neutral world, where men define the parameters of citizenship, women are reduced to being lesser men. These are the two horns of the dilemma first identified by the eighteenth-century philosopher, Mary Wollstonecraft, whose insights in the Vindication of the Rights of Woman help us to understand the problems in making claims based on women's difference or equality with men.

The authors in this book recognize the perpetuation of this classic dilemma as well as the evolution and mutations of the public/private dichotomy. Gerhard, Knijn and Lewis (Chapter 5) revisit the classical idea of the social contract, which was erected on the separation of the public and private, and consider the way in which recent assumptions regarding a nongendered adult worker and consumer of social services has allowed the "contractualization' of whole areas of collective provision and the private sphere of the family. They argue that the unequal division of paid and unpaid work in particular makes it difficult to treat men and women as having equal capacities to contract; the move towards contractualization assumes the widespread existence of a worker-citizen model based on traditional male behaviour in the public sphere of the labour market. The contestations around care also involve distinguishing what is public and private. According to Leira and Saraceno (Chapter 3), the very definitions of care, as well as the 
social politics around it, revolve around the fuzzy lines drawn between public and private care. Their analysis reveals the difficulties of drawing these boundaries. While concepts such as social care seek to delineate the social care provisions from care in the private home, in many countries there are now policy formulas designed to commodify the care work done by relatives. We have to think about caring regimes that reveal the complex mix of paid and unpaid, formal and informal, private and public care. Whereas we would agree that the distinctions between public and private domains are social constructions (Fraser, 1989), we retain the analytical distinction in order to reveal the contested and dynamic flows between the public and private, in order to find new ways of articulating the tensions within them.

The chapters in this book reveal that Wollstonecraft's dilemma has become a many-sided dilemma, the result of the different challenges to the category of woman coming from different quarters. The post-modern turn in the social sciences called into question fixed identities and categories. The dilemma of difference has become the dilemma of differences. When Denise Riley poignantly asked woman: Am I That Name? (1988), she captured a decade of unease in conjoining women from different historical eras, classes, races, ethnicities, degrees of ableness, sexual preferences, ages, religions and regions into the unitary category woman. Black women scholars posed a frontal challenge to the interpretative frameworks of white feminists, claiming that their analysis, which located women's oppression in the patriarchal relations of the family, did not fit with the situation of black women, for whom the family was often a site of resistance against the invasive policies of the state and the discrimination in the market. The same critique was echoed by women from the former Soviet Union when they encountered the theories of private patriarchy versus public patriarchy (Ferree, 2000). Finally, speaking from the standpoint of the critical studies of men, the main voices in that research tradition have emphasized the plurality of masculinities, that men have different subjectivities, practices, loyalties and interests, including gay versus straight, black versus white, upper class versus working class and so on.

Hobson and Lister (Chapter 2) recognize that a politics of difference traverses across and through the web of group differences and ask how one articulates 'a politics of solidarity in difference' without suppressing or freezing the multiple identities of citizens. They realize that acknowledging a gender-pluralist citizen model may result in a loss of citizenship's function as a universal measure against which marginalized groups can measure their progress towards full inclusion, adding yet another horn to the dilemma of difference when confronting issues of citizenship and inclusion. MarquesPereira and Siim (Chapter 7) highlight the complexities of the inclusionary strategies to increase women's representation in politics. Arguments for 
parity and quotas come up against questions of who represents whom and what is being represented. This is to ask whether mere numbers of women will in fact represent the collective goals of a group. More specifically these inclusionary strategies raise issues concerning women's agency: whether women can mobilize around core issues despite differences, perhaps with common points of interest and consensus around particular concerns such as discriminatory patterns in work, biopolitics and so on. This is to recognize the validity of feminist action within feminisms.

The conflicting logic between an ethic of care based on relations in the family, and an ethic of justice based on civil, political and social rights has been an important starting point for feminist theorizing about the boundaries around paid and unpaid work. The chapter on commodification and de-commodification (Chapter 6) traces the dynamic and history of the process of turning use-value-oriented activities, in particular, the work of caring for others, into labour or paid work. As Knijn and Ostner note, the logic of the respective activity changes in the process of commodification from having primarily a use value for those involved, to an exchange value for the wage-dependent labourer who has to make a living. Hitherto settled care relationships are currently in flux, and they observe that both the commodification of private care relationships, for example the commodification of work within the household and payments for care, together with the introduction of market principles in public sector care work, serve to reconcile work and care, but not necessarily according to feminist principles. Their analysis reveals that attention to the latter requires a policy of balancing commodified and non-commodified work. Arguably public services are an answer to the demand for the better arrangement of paid work and care, but the current EU appeals to reconcile work and care focus primarily on increasing women's employment and neglect the fact that high-quality care is expensive. One way to move beyond commodification is longer and more flexible maternity/paternity and parental leave measures, although such policies have tended thus far to stabilize the gender division of care.

Feminist scholars have during the last 30 years illuminated genderspecific patterns of exclusion and inclusion in relation to democracy, citizenship and welfare states; they have explored the contextual nature of social policy cross-nationally; and they have examined the different role of women's organizations and associations in the evolution of civil, social and political rights (Koven and Michel, 1993; Bock and James, 1992; Lewis, 1992; Siim, 2000). Their comparative perspective challenges the universal gender-blind stories about the evolution of welfare states and points towards the different dynamics of the evolution of women's and men's civil, political and social rights. 
The contributors to this volume work within various conceptual frameworks and from different national contexts but they share some basic premises: gender matters, context matters and politics matters (Siim, 2000). Gender matters in the sense that the concept of gender is a means to destabilize gender-blind thinking and often to rethink key concepts in social and political theory. Feminist scholarship suggests that gender can be used as a lens for understanding the meaning of the key concepts of public and private arenas, equality and difference, and paid work and care. Feminist research has shown the way in which gender can also be employed as a means to gain knowledge of fundamental processes of reproduction and change in socio-economic structures and about path dependencies and shifts in policy logics in political institutions. Comparative scholarship has illuminated the different ways gender, together with class, have been the major structuring concepts in the evolution of the modern welfare states.

Context matters in the sense that different historical trajectories, legal traditions, political institutions and cultures make up systems of welfare, citizenship and democracy, with implications for gender equality. Our cross-national dialogues have highlighted the importance of the different national policy logics and the different welfare and caring regimes. Feminist scholarship has noted that historically a tendency towards a male breadwinner norm often cuts across the different welfare regimes, and has identified different 'caring' and 'gender' regimes built on the relation between paid work and care work, between the family, state and market: (a) the Nordic model that is based on state-delivered welfare; (b) the familialistic model that leaves responsibilities of care to the family; (c) the liberal model that leaves responsibility of care to either the family or the market. (Lewis, 1992, 1993; Leira, 1992; Daly and Lewis, 2000; Siim, 2000). Different welfare and caring regimes are also connected to legal systems with unequal legal and juridical rights of husband and wife and/or mother and father relations ${ }^{5}$ (Therborn, 1995). These are different models of family and welfare that have a different perception of the meaning of the public and private, as well as of the relation between the family, the state and the market. They have also had different implications for gender equality and for the evolution of women's civil, political and social rights, and they may indeed be understood as four different gender systems, which are undergoing profound restructuring.

Politics matters in the sense that institutions, legal traditions and culture, as well as collective actors in civil society and the public arena, influence the development of welfare states. Comparative research illustrates the multiple ways that collective actors, for example the workers and peasant movements, trade unions and religious organizations, have influenced the development of social politics. Feminist scholarship has shown that 
women's organizations have also, at least in some countries in respect of some issues, been able to influence social politics in the interest of particular groups of women. In the past women primarily succeeded in influencing social politics 'from below', through voluntary organizations and social movements, but during the last 30 years women have also been able to influence politics 'from above' in many countries, through participation and representation in public institutions, especially in the Nordic countries. One key question is to what extent women's collective organizations/agency will be able to influence the present restructuring of the welfare states as well as the future process of European integration, and to put women's issues and interests on the political agenda. The current process of restructuring welfare states has made the dilemmas arising from women's paid work visible: attempts to encourage mothers to take paid work tend to increase the 'care deficit' in society if they are not accompanied by an expansion of public child care services.

One of the crucial themes at the forefront of the analysis presented in this book is the importance of feminist political activism and feminist scholarship to the gendering of inequality during the past 30 years, which has resulted in the demands for greater civil, political and social rights. The feminist movement in all Western democracies has put gender equality on the political agenda. Feminism as an ideology has challenged the dichotomizing of public and private, paid and unpaid care work, equality and difference. Feminist scholarship, inspired by feminist politics, has started to rethink the relationships between the family, the market and the state. The flow of ideas across national borders in feminism has been a catalyst for comparative research about women's empowerment and the role of political women's agency in influencing governments' decision making and the development of social policies. We have not included either equality or power as distinct concepts in the book, but they are implicit in all the chapters, which address the impact of theoretical approaches, discursive practices and social politics on gender equality and women's agency, power and ability to influence political decisions.

There are many parallel conversations in the different chapters, which illustrate the interconnectedness of the core concepts and their social politics. For example, the chapters on citizenship and on social exclusion both address questions about the inclusion and exclusion of women as mothers, workers and citizens. Those on citizenship and representation consider the possibilities for and constraints on women's inclusion in democracy, and recognize the links between women's social and political rights. There are intersecting points within the chapters on contractualization, (de-) commodification and care that revolve around the relationship between paid work and politics of care in relation to welfare state restructuring, 
albeit from different theoretical standpoints. Finally the chapter on representation speaks to the chapter on social capital insofar as they both focus on the issue of democratic participation.

Today feminist theory and research has to some extent become part of the interdisciplinary dialogue about the transitions in welfare states, democracy and citizenship (Esping-Andersen, 1999; Habermas, 1998). Moreover, there are indications that gender has also started to enter mainstream theory and research in social politics, for example in welfare regime models, though, of course, the integration of gender is an uneven and contradictory process, and there are crucial differences between the importance of gender in the different disciplines and national contexts. The chapters in this volume illustrate these differences in the gendering of theoretical landscapes. They also highlight the instability of conceptual terrains in this period of welfare state restructuring and extensive globalization. Through our contested concepts, we have been able to track these shifting markings and fluctuating boundaries with a gendered compass.

\section{NOTES}

1. The European Network on Theory and Research on 'Women, Welfare State and Citizenship' was founded in 1991 and celebrated its ten-year anniversary in June 2001; it is co-ordinated by Trudie Knijn, Utrecht University.

2. The EC network: Gender and Citizenship: Social Integration and Social Exclusion in European Welfare States (1996-1999) was co-ordinated by Birte Siim, one of the editors of this book, and it has produced five seminar reports and a number of articles.

3. It was directly inspired by a doctoral course at Stockholm University of the same name, taught by Barbara Hobson, one of the editors of this book.

4. The term 'de-familialization' refers to policies that lessen individuals' reliance on the family and maximize individuals' command of economic resources independently of familial and conjugal obligations. It is a bit difficult to trace, because it has been used around the same time by a number of feminist researchers as an alternative to social policies that increased women's economic dependency on individual husbands (see McLauglin et al., 2001; Lister, 1997; Saraceno, 1997). De-familialization has recently been incorporated, or indeed appropriated, into the framework of Esping-Andersen as a key concept next to de-commodification, designating the key role of households in the new post-industrial economy (1999, pp. 45-6).

5. In the book European Modernity and Beyond: Trajectory of European Societies 1945-2000 the Swedish sociologist Göran Therborn has identified four legal systems: (a) the English common law; (b) Code Napoleon; (c) the German civic law; (d) the Nordic marriage law, and he has conceptualized the legal systems as four forms of legal patriarchy (Therborn, 1995, pp. 104-9). The four systems thus each represent a gender system with unequal legal rights of men and women and different gender dynamics. Although it is not clear what the relation is between the legal traditions and welfare state developments, it has been argued that at least in the Nordic case the marriage reform between 1909 and 1925 based on equal individual rights of both spouses was indeed a prerequisite for the development of the welfare state. 


\section{BIBLIOGRAPHY}

Bergqvist, C., A. Borchorst, A.D. Christensen, N. Raaum, V. Ramnstedt-Silén and A. Styrkasdottir (eds) (1999), Equal Democracies? Women and Politics in the Nordic Countries, Oslo: University Press.

Blair, T. and G. Schroeder (1999), Europe: The Third Way - die Neue Mitte, London: Labour Party and SPD.

Bock, Gisela and S. James (1992), Beyond Equality and Difference: Citizenship, Feminist Politics and Female Subjectivity, London and New York: Routledge.

Bowles, S. (2000), 'Globalization and Economic Justice', Benjamin H. Hibbard (ed.), Memorial Lecture, University of Wisconsin-Madison, 1 March.

Bradshaw, J., A. Corden, T. Eardley, H. Holmes, S. Hutton, S. Kennedy, M. Kilkey and J. Neale (1996), The Employment of Lone Parents, London: Family Policies Study Centre, T.1.3.

CEC (1993), Growth, Competitiveness and Employment - the Challenges and Ways forward into the 21st Century, Luxembourg: CEC.

CEC (1995), Equal Opportunities for Women and Men - Follow-up to the White Paper on Growth, Competitiveness and Employment, Brussels: DGV.

Cm. 41921-I (1999), With Respect to Old Age, Report of the Royal Commission on Long-term Care, Norwich: The Stationery Office.

Crompton, R. (ed.) (1999), Restructuring Gender Relationships and Employment: the Decline of the Male Breadwinner, Oxford: Oxford University Press.

Daly, M. and J. Lewis (2000), 'The Concept of Social Care and the Analysis of Contemporary Welfare States', British Journal of Sociology, 51 (2), 281-98.

Dingledey, I. (2000), 'International Comparison of Tax Systems and their Impact on the Work-family Balance', paper presented at the EC TSER seminar, 23-25 March, Paris.

Duncan, S. and R. Edwards (1999), Lone Mothers, Paid Work and Gendered Moral Rationalities, Basingstoke: Macmillan.

Esping-Andersen, G. (1999), Social Foundations of Postindustrial Economics, Oxford: Oxford University Press.

Esping-Andersen, G. (2000), 'Challenge to the Welfare State in the 21st Century. Ageing Societies, Knowledge Based Economies and the Sustainability of European Welfare States', paper presented at the conference on Comparer les Systémes de Protection Sociale en Europe, Ministère de L'Emploi et de la Solidarité, Paris, 8-9 June.

Ferree, M.M. (2000), 'Patriarchies and Feminisms: The Two Women's Movements of Post-unification Germany', in B. Hobson (ed.), Gender and Citizenship in Transition, Basingstoke: Macmillan, pp. 156-72.

Folbre, N. (1994), Who Pays for the Kids? Gender and the Structures of Constraint, London: Routledge.

Fraser, N. (1989), Unruly Practices: Power, Discourse and Gender in Contemporary Social Theory, Minneapolis: University of Minnesota Press.

Fraser, N. and L. Gordon (1994), "Dependency" Demystified: Inscriptions of Power in a Keyword of the Welfare State', Social Politics: International Studies in Gender, State and Society, 1 (1), 4-32.

Gal, S. and G. Kligman (2000), The Politics of Gender After Socialism, Princeton: Princeton University Press.

Glennerster, H. and J. Hills (eds) (1998), The State of Welfare: The Economics of Social Spending, Oxford: Oxford University Press. 
Glennerster, H. (1999), 'Which Welfare States are most Likely to Survive?', International Journal of Social Welfare, 8, 2-13.

Gough, I. (1996), 'Social Welfare and Competitiveness', New Political Economy, 1 (2), 209-32.

Habermas, J. (1998), Between Facts and Norms: Contributions to a Discourse Theory of Law and Democracy, Cambridge, MA: MIT Press.

Hakim, C. (1996), Key Issues in Women's Work: Female Heterogeneity and the Polarization of Women's Employment, London: Athlone.

Hills, J. (ed.) (1990), The State of Welfare: The Welfare State in Britain Since 1974, Oxford: Clarendon Press.

Hobson, B. (ed.) (2000), Gender and Citizenship in Transition, Basingstoke: Macmillan.

Hobson, B. (ed.) (2001), Making Men into Fathers: Men, Masculinities and the Social Politics of Fatherhood, Cambridge: Cambridge University Press.

Hochschild, A. (1995), 'The Culture of Politics: Traditional, Post-modern, Coldmodern and Warm-modern Ideals of Care', Social Politics, Fall, 331-46.

Hoven, B. (2001), 'The Problem with Democracy: Women in Rural East Germany', Social Politics: International Studies of Gender, State, and Society, 8 (2).

Jordan, B. (1998), The New Politics of Welfare, London: Sage.

Koven, S. and S. Michel (eds) (1993), Mothers of a New World: Maternalist Politics and the Origin of the Welfare States, New York and London: Routledge.

Leira, A. (1992), States and Working Mothers: the Scandinavian Experience, Cambridge: Cambridge University Press.

Levy, J. (1999), 'Vice into Virtue? Progressive Politics and Welfare Reform in Continental Europe', Politics and Society, 27 (2).

Lewis, J. (1992), 'Gender and the Development of Welfare Regimes', Journal of European Social Policy, 2 (3), 159-73.

Lewis, J. (1993), Women and Social Policies in Europe: State, Work and Family, Aldershot: Edward Elgar.

Lewis, J. (ed.) (1997), Lone Mothers in European Welfare Regimes: Shifting Policy Logics, London and Philadelphia: Jessica Kingsley Publishers.

Lewis, J. (2000), 'Work and Care', in H. Dean, R. Sykes and R. Woods (eds), Social Policy Review, 12, London: Social Policy Association, pp. 48-67.

Lewis, J. (2001), The End of Marriage? Individualism and Intimate Relationships, Cheltenham: Edward Elgar.

Lister, R. (1997), Citizenship: Feminist Perspectives, Basingstoke: Macmillan.

Marchand, M.H. and A.S. Runyan (2000), Gender and Global Restructuring: Sightings, Sites and Resistances, London: Routledge.

McLaughlin, E., J. Trewsdale and N. McCay (2001), 'The Rise and Fall of the UK's First Tax Credit: The Working Families Tax Credit, 1998-2000', Social Policy and Administration, 35 (2), 163-80.

Mead, L. (1986), Beyond Entitlements: The Social Obligation of Citizenship, New York: The Free Press.

O'Reilly, J. and C. Fagan (1998), Part-time Prospects: An International Comparison of Part-time Work in Europe, North America and the Pacific Rim, London: Routledge.

Piachaud, D. (2000), 'International Social Welfare and the Impact of Globalization', unpublished address.

Pierson, P. (ed.) (2001), The New Politics of the Welfare State, New York: Oxford University Press. 
Plant, R. (1998), New Labour - A Third Way?, London: European Policy Forum.

Rake, K. (2000), 'Gender and New Labour's Social Policies', Journal of Social Policy, 30 (2), 209-32.

Riley, D. (1988), Am I that Name? Feminism and the Category of Women in History, Minneapolis: University of Minnesota Press.

Rubery, J., M. Smith and C. Fagan (1999), Women's Employment in Europe: Trends and Prospects, London: Routledge.

Sainsbury, D. (1994), Gendering Welfare Regimes, New York and London: Routledge.

Saraceno, C. (1997), 'Family Change, Family Policies and the Restructuring of Welfare', in OECD, Family, Market and Community, Social Policy Studies 21, Paris: OECD.

Scheiwe, K. (1994), 'EC Law's Unequal Treatment of the Family: The Case Law of the European Court of Justice on Rules Prohibiting Discrimination on Grounds of Sex and Nationality', Social and Legal Studies, 3 (2), 243-65.

Siim, B. (2000), Gender and Citizenship: Politics and Agency in France, Britain and Denmark, Cambridge: Cambridge University Press.

Stephens, J.D., E. Huber and L. Ray (1999), 'The Welfare State in Hard Times', in H. Kitscheldt, P. Lange, G. Marks and J.D. Stephens (eds), Continuity and Change in Contemporary Capitalism, Cambridge: Cambridge University Press, pp. 164-93.

Supiot, A. (1999), Au Delà de L'Emploi, Paris: Flammarion.

Szalai, J. (2000), 'From Informal Labor to Paid Occupations: Marketization from Below in Hungarian Women's Work', in S. Gal and G. Kligman (eds), Reproducing Gender: Politics, Publics, and Everyday Life after Socialism, Princeton: Princeton University Press.

Tanzi, V. (2000), 'Globalization and the Future of Social Protection', IMF Working Paper.

Therborn, G. (1995), European Modernity and Beyond: The Trajectory of European Societies 1945-2000, London: Sage Publications.

Therborn, G. (2000), 'Globalizations: Dimensions, Historical Waves, Regional Effects, Normative Governance', International Sociology, 15 (2), 151-79.

Vandenbroucke, F. (1998), Social Democracy, Globalization and Inequality, London: IPPR.

Visser, J. and A. Hemerijcke (1997), A Dutch Miracle, Amsterdam: University of Amsterdam Press.

Williams, R. (1983), Keywords: A Vocabulary of Culture and Society, revised edition, New York: Oxford University Press.

Wilson, W.J. (1987), The Truly Disadvantaged, Chicago: Chicago University Press. 